УДК 930.130 .2

DOI https://doi.org/10.32837/apfs.v0i27.913

\author{
Д. Л. Кобелєва \\ ORCID ID: https://orcid.org/0000-0003-3139-1561 \\ кандидат філософських наук, \\ старший викладач кафедри ЮНЕСКО «Філософіл людського спілкування» \\ та соиіально-гуланітарних дисииплін \\ Харківського національного технічного університету сільського господарства \\ імені Петра Василенка
}

\title{
СУЧАСНІ ТЕХНОЛОГІЇ ТА ПРОЄКТУВАННЯ ЛЮДСТВА (СПІЛЬНЕ ТА РІЗНЕ У ФУТУРИСТИЧНИХ КОНЦЕПЦІЯХ М. КАКУ ТА Ю. Н. ХАРАРІ)
}

Постановка проблеми. На порозі XXI століття стає все більш зрозумілим, що найближчим часом людство зазнає глобальних змін. Зміняться соціальні системи, зміниться сама сутність людини. 3 одного боку, це далеко не перша ситуація в істоpiï, коли людина зазнає суттєвих змін (починаючи від біологічних властивостей та закінчуючи формуванням нових соціально-політичних систем), 3 іншого боку, це, можливо перша ситуація, коли сутність людини та форми ї̈ існування можуть змінитися настільки, що саме поняття «людина» втратить свій сенс, іншими словами, людина зникне, давши життя чомусь принципово новому.

Основною причиною можливого розвитку подій у цьому напрямі є розвиток техніки та технологій. Феномен техніки є досить суперечливим, але неможливо відкидати той факт, що технічний прогрес лежить в основі сучасної цивілізації. Можна сказати, що техніка є одним із визначальних факторів формування культури та світогляду людства. Водночас, створивши найбільш гуманістичну культуру за всю історію людства, наука та техніка можуть найближчим часом покласти край самому людству.

3 огляду на це проблема майбутнього людства набуває неабиякої актуальності, в тому числі в межах філософських роздумів. Проблеми визначення сенсів буття людини, розуміння сутності людини та ії̈ меж, формулювання цілей та стратегій майбутнього розвитку стають дуже важливими для сучасного суспільства, тому потребують уважного та всебічного розгляду. Оскільки всі зазначені питання є традиційними для філософії, то філософський аналіз можливих перспектив взаємодії людини з технікою може суттєво вплинути на хід історії [2].

Аналіз останніх досліджень і публікацій з цієї теми. У статті ми пропонуємо порівняти футуристичні прогнози двох відомих учених та популяризаторів науки, а саме Мітіо Каку, професора теоретичної фізики, одного із засновників теорії струн, що є однією з головних теорій сучасної фізики, та Юваля Ноя Харарі, історика, професора Єврейського університету в Єрусалимі.
М. Каку досліджує новітні технології та їх наслідки в межах різних наук (фізики, біології, когнітивних наук тощо) і намагається побудувати модель майбутнього людства. Він також акцентує увагу та проблемних зонах сучасних досліджень та перспективах їх вивчення. У статті ми будемо спиратися на книгу М. Каку «Майбутне розуму», в якій він робить спробу дати визначення такого фундаментального феномена внутрішнього світу людини, як свідомість, проаналізувати можливості його утворення, існування та змін під впливом різноманітних факторів, уявити можливості подальшого його розвитку та визначити майбутні форми існування свідомості.

Ю.Н. Хapapi у книгах «Sapiens: Коротка історія людства» та «Homo Deus: Коротка історія майбутнього» робить спробу проаналізувати погляди сучасних учених на основні етапи історії людської цивілізації, виділити ключові моменти історії, які трансформували сутність людини та її відносини 3 навколишнім середовищем. Ю.Н. Харарі Ірунтовно розглядає питання про те, коли й чому техніка почала активно розвиватися і впливати на розвиток культури, що, зрештою, очікує людство в контексті прогресу науки і технологій.

Мета статті полягає в тому, щоби порівняти результати досліджень М. Каку та Ю.Н. Харарі, зіставити їх ідеї щодо перспектив людства та загроз, які виникають у нього на шляху, а також пов'язані з наслідками науково-технічного прогресу; проаналізувати погляди цих учених на проблеми, які ставлять перед сучасною культурою наука й техніка, та можливі шляхи їх подолання; розглянути філософськи питання сучасності, без вирішення яких майбутне людства може опинитися під загрозою. В межах філософії однією з центральних проблем завжди була проблема сенсу в різних ії інтерпретаціях. Нині ця проблема набуває особливого значення. Перед філософією та іншими гуманітарними науками постає реальне завдання пошуку сенсу життя для майбутнього людства. Ми не можемо уявити, в яких формах буде відбуватися буття людини, але ми можемо закласти сенс цього буття [3, с. 65]. 
Виклад основного матеріалу дослідження. Протягом усієї своєї історії людство розвивалося в межах органічного світу. Однак зараз розвиток науки і технології дає змогу вийти за межі органічної системи та продовжити буття людини в неорганічному світі. Це вже дає необмежені можливості розвитку людської цивілізації [3, с. 64]. Саме навколо цих можливостей, їх особливостей та способів реалізації обертаються ідеї М. Каку та Ю.H. Хapapi.

Ю.Н. Харарі вважає, що людство в ході свого розвитку пройшло три основних етапи, в результаті чого сформувалися сучасна людина та сучасна культура. Для того щоби краще зрозуміти ідеї цього автора щодо майбутнього людства, треба розглянути його концепцію трьох революцій. «Хід людської історії визначили три найвизначніші революції. Почалося з когнітивної революції, 70 тисяч років тому. Аграрна революція, що відбулася 12 тисяч років тому, істотно прискорила прогрес. Наукова революція - їй всього лише 500 років - цілком здатна покінчити з історією і започаткувати щось інше, небувале» [5, с. 9-10]. Ю.Н. Харарі в книзі «Sapiens: Коротка історія людства» детально аналізує, як розвивались людина та її здібності з переходом від однієї стадії до іншої. Перша революція - когнітивна - поклала початок історії Людини Розумної. В цей період людство навчилось будувати міфи (не в останню чергу завдяки особливостям мови) та сплітати павутиння сенсів, яке досі є основою культури. Вже завдяки міфам люди навчилися взаємодіяти у великих групах, що стало основною причиною процвітання виду на Землі. Аграрна революція навчила людину трансформувати реальність «під себе», а також «надала майбутньому небувале раніше значення. Хлібороб змушений постійно думати про майбутнє і працювати на нього» [5, с. 122]. Когнітивна революція, яку Ю.Н. Хараpi називає "доленосним вибором», навчила людство вірити у прогрес, феноменальні можливості науки щодо вирішення будь-яких завдань. Отже, когнітивна революція «обгрунтувала» необхідність поєднання науки, техніки та фінансових ресурсів, в результаті чого наука з творчої діяльності обраних перетворилась на головну справу цивілізації загалом. «В останні півтисячоліття люди поступово впевнилися, що зможуть істотно розширити свої можливості, якщо витратяться на наукові дослідження» [5, с. 296]. Таким чином, із часів когнітивної революції людство почало вірити в те, що майбутнє буде обов'язково кращим, необхідно якомога сильніше розвивати науку та технології. Так виникає ідея прогресу.

Отже, можна стверджувати, що сучасну культуру визначає декілька факторів, яких людство набувало протягом усієї своєї історії. До них належать здатність створювати інтерсуб’єктивну реальність сенсів та налагоджувати глобальну взаємодію, віра в майбутнє та ідея науковотехнічного прогресу. На основі цих моментів формується як соціальна, так і ідеологічна структури. Визначається природа та сенс життя людини, пріоритети людства загалом та його цілі. «Один з істотних факторів, що зберігають сучасний соціальний уклад, - поширеність майже релігійної віри в технології і в методи наукового дослідження» [5, с. 301], - пише Ю.Н. Харарі.

3 огляду на це не дивно, що техніка посідає все більш значуще місце в житті людини та цивілізації загалом. Поєднання гуманістичної ідеології та результатів технічного прогресу визначають цілі розвитку людства. Ю.Н. Харарі вважає, що найближчими цілями цивілізації стануть «безсмертя, щастя і божественність» [4, с. 30]. Однак саме на цьому шляху поєднання гуманізму і сучасних технологій людство має всі шанси зникнути назавжди.

Для того щоб зрозуміти, можливі сценарії розвитку подій у майбутньому, треба зупинитись більш детально на розгляді особливостей людської свідомості та її можливостей. Свідомість людини $є$ витоком ідей, цілей, пріоритетів та стратегій, цінностей та цілей. Однак виявляється, що сучасна наука поки що не здатна дати однозначні відповіді на ці запитання.

М. Каку починає свою книгу «Майбутне розуму» такими словами: «Дві найбільші загадки природи - розум і Всесвіт. За допомогою сучасної техніки ми можемо фотографувати галактики <...>, маніпулювати генами <...> і зондувати глибини атома, але розум і Всесвіт, як і раніше, не даються, вислизають і дражнять нас. Це найзагадковіші і найбільш захоплюючий з усіх відомих науці рубежів» $[1$, с. 7]. М. Каку підкреслює, що протягом більшої частини історії люди не були спроможні зазирнути в таємниці мозку, але зараз, із появою МРТ-сканерів, ситуація дуже покращилась. Зокрема, вчені вперше отримали змогу вивчати свідомість, спираючись на емпіричні дослідження.

М. Каку формулює концепції свідомості таким чином: «свідомість є процес створення моделі світу з використанням безлічі зворотних зв'язків за різними параметрами» [1, с. 65]. Свідомість тварин переважно працює в просторі, тоді як «людина йде далі і розгортає свою модель світу в часі, причому як вперед, так і назад» [1, с. 66]. Таке формулювання збігається з твердженням Ю.Н. Харарі про те, що людство набуло своїх сучасних рис, коли навчилось моделювати майбутнє. Однак, незважаючи на те, що свідомість відіграє фундаментальну роль у житті людини та людства загалом, наука поки що не здатна дати остаточну відповідь щодо того, яким саме чином вона формується та яким чином пов'язана 3 діяльністю мозку. Спираючись на дослідження мозку, М. Каку звертає увагу на те, 
що, наприклад, обидві півкулі можуть породжувати окремі свідомості. Чим тоді є свідомість, коли іï можна поділити навпіл? [1] «Чим краще ми розуміємо мозок, тим більшою надмірністю здається розум», - вважає Ю.Н. Харарі [4, с. 133]. Він намагається зрозуміти, яку біологічну функцію виконує свідомість, для чого саме вона потрібна, і доходить висновку про те, що принаймні сучасна наука не здатна відповісти на це запитання. Виявляється, що свідомість просто існує і для суто біологічного існування не виконує ніяких функцій. Однак сучасна соціальна система міцно зав' язана на такому продукті діяльності мозку, як свідомість. Можливо, вона є побічним продуктом діяльності мозку і сама по собі не має ніяких функцій. Ю.Н. Харарі вважає, що це найбільш адекватна теорія свідомості сьогодні [4, с. 140-141].

3 вищезазначеної проблеми випливає не менш складне питання, яке безпосередньо пов'язане із сучасною культурою людства та їі пріоритетами, такими як проблема людської індивідуальності, проблема центру свідомого буття людини - ¥ї «Я». Спостерігаючи за роботою мозку, можемо відстежити електричні імпульси, нейронні шляхи тощо, але вченим поки що не вдалося знайти певний фізичний центр цих процесів, тобто те, що формує відчуття самості або єдності психічних процесів людини. «Де шукати «Я»? - запитує М. Каку [1, с. 87]. Він доходить висновку, що, скоріше за все, існує «особлива частина мозку, завдання якої - об'єднувати сигнали від двох півкуль і формувати єдине, цілісне відчуття самості» [1, с. 87]. «Ліва півкуля відповідає за прагнення людини відшукати порядок у хаосі, скласти всі факти в пов' язану несуперечливу історію, а історію вставити в контекст. Схоже, ліва півкуля намагається будувати гіпотези про структуру світу навіть тоді, коли все свідчить про те, що ніякої структури у нього немає», - продовжує М. Каку [1, с. 89].

Виникає питання про те, яким чином усі вищезазначені проблеми впливають на долю людства. На думку Ю.Н. Харарі, безпосередньо. Розмірковуючи над підвалинами сучасної культури (отже, над її перспективами), він зауважує, що їх складає віра в гуманістичні цінності, а гуманізм неможливий без віри в єдине та неподільне «Я», яке має свободу волі. Саме впевненість у тому, що людина є справжньою цінністю та має унікальну природу, що ця природа визначає цілі та сенси, є основою сучасної політики, науки та культури загалом [4]. Однак якщо підходити до проблеми «Я» з точки зору сучасної науки, виявляється, що ніякого єдиного центру особистості не існує. «Наука підриває не лише ліберальну віру у вільну волю, але й віру в індивідуалізм» [4, с. 340]. Скоріше, внутрішній світ людини складається з багатьох «голосів», які конкурують між собою. Отже, цілком можливо, що, замислившись, зрештою, над цим питанням, людство має визнати, що воно не має ніяких особливих прав, а проблема сенсу буття стане ще більш складною, тому що складно буде визначити навіть центр цих сенсів, не говорячи вже про їх обгрунтованість. Проблема багатьох «Я» є однією з тих, що може спричинити суттєві трансформації сутності людини.

Однак навіть дотримуючись гуманістичних ідеалів, людство має всі шанси покласти край своєму існуванню. Ю.Н. Харарі зазначає, що найближчі цілі людства (безсмертя, щастя та божественність) є нічим іншим, як поєднанням гуманістичних цінностей та сучасних технологій. Сучасна біологія, медицина та комп'ютерні науки досягли вже такого рівня, що одвічні мрії людства стають суто технічними проблемами, які наука так чи інакше має вирішити. Однак «спроба реалізувати гуманістичну мрію підірве її власні основи, вивільнивши нові, постгуманістічні технології» [4, с. 325]. Отже, на думку Ю.Н. Харарі, цілком можливо, що технології в погоні за гуманістичними цілями приведуть до зовсім «негуманістичних» наслідків.

Головна ідея, спільна для Ю.Н. Харарі та M. Каку, полягає в тому, що найближчим часом людина зіллється з технікою. Власне, цей процес уже почав відбуватися. Якщо донедавна людина була впевнена в тому, що вона має якусь особливу сутність, яка не може бути «прорахована», отже, штучний інтелект ніколи не зрівняється 3 людиною та не перевершить їі (хіба що в деяких аспектах), то сучасна наука, як виявилось, принаймні поки що, не знайшла нічого принципово унікального в алгоритмах людини. Саме поняття «життя» вже не здається очевидним. Немає ніяких суттєвих перешкод для того, щоби штучні алгоритми, зрештою, стали «живими». Принаймні вони цілком можуть розвитися до такої стадії, що буде неможливо відрізнити їх від справжніх людей.

Що очікує людство в такому разі? Можливо, воно зникне, а можливо, зіллється зі штучним інтелектом. В будь-якому разі, скоріше за все, біологічна ера підходить до свого завершення, плавно переходячи в еру технологічну.

Технології все ближче й ближче підходять до того, щоб розшифрувати мозок людини. М. Каку зазначає, що зараз паралельно реалізуються два різних підходи, метою яких є реконструкція всіх процесів та зв'язків, які існують у мозку людини. Що це може означати для людства? Тотальну трансформацію основних життєвих процесів. Якщо мозок більше не пов'язаний з біологічним тілом, нічого не заважає замінювати тіла на більш досконалі та потужні, управляти тілом на відстані, або взагалі існувати без тіла [1, с. 15].

«Однак як тільки технології дадуть нам змогу реконструювати людський мозок, Homo Sapiens зникне, історія людства закінчиться і почнеться абсолютно новий, недоступний нашому з вами 
розумінню процес» [4, с. 59], - пише Ю.Н. Харарі. «Після чотирьох мільярдів років блукань по царству органічних структур життя вирветься на простори неорганічного світу і набуде таких форм, які нам не насняться в найстрашнішому сні» [4, с. 57]. Ю.Н. Харарі зазначає, що завдяки сучасній біології людина вперше в історії отримала змогу проєктувати біологічний світ на свій розсуд. Природній відбір, який дотепер керував процесом створення та трансформації біологічних істот, виходить на другий план. Генна інженерія дає змогу вченим трансформувати живі істоти, зокрема людину, за своїм бажанням. «Намічаються три шляхи витіснення природного відбору продуманим дизайном: біоінженерія, створення кіборгів (кіборги - живі істоти, що поєднують органічні і неорганічні частини), створення неорганічного життя» [5, с. 473].

Всі зазначені підходи мають спільну рису. Річ у тім, що сучасна наука дивиться на людину як на один із алгоритмів. Можливо, це лише один із етапів розвитку уявлень про природу людина, заснований на порівнянні із системами штучного інтелекту, а можливо, достовірне знання. Навіть якщо це лише вірогідне припущення, сучасні технології, взявши його за основу, цілком можуть переробити життя таким чином, що такий підхід стане актуальним для нової реальності.

Можливо, некоректно порівнювати людину з комп'ютером, який нічого не хоче і нічого не відчуває, як зазначає Ю.Н. Харарі. Хоча, з іншого боку, з часом комп'ютер стане настільки складним, що у нього з'явиться свідомість [4, с. 142]. М. Каку теж говорить про те, що «колись, коли роботи перевершать нас у здібності маніпулювати словами та відчуттями, питання про те, чи «розуміють» вони їх та чи «відчувають», не матиме сенсу» $[1$, с. 342$]$. В цей момент на перший план вийде проблема недоказовості свідомості іншого, неможливо буде відрізнити комп'ютер від людини. «Існують побоювання, - пише М. Каку, - що люди можуть програти в інтелекті свідомим роботам. <...> Завдяки здатності краще моделювати майбутнє роботи змогли би перебрати безліч сценаріїв та знайти найкращий спосіб повалити людство» [1, с. 348]. Він пише, що «нам доведеться примиритися з думкою про те, що ми і самі машини. Це означає, що одного разу ми зможемо створити машини, які будуть не менш живі, ніж ми самі. <...> Нам доведеться відмовитися від концепції нашої «особливості»» [1, с. 354].

Таким чином, на думку М. Каку та Ю.Н. Хаpapi, найближчим часом людство може одночасно стикнутися з двома глобальними проблемами. Перша проблема світоглядна і пов'язана з тим, що люди звикли розташовувати себе в центрі Всесвіту або покладати у своїй основі певну сутність, яка не може бути зведена до набору електричних імпульсів мозку та не піддається обчислюванню. Поки що так і є. Свідомість людини, або їі розум, має всі підстави для того, щоби вважатися унікальнім. Нічого подібного ми не спостерігаємо навіть у дуже складних систем штучного інтелекту. Поки що в експертних системах повністю відсутні самосвідомість та здоровий глузд, на чому наголошуе М. Каку [1, с. 307]. В жодної комп’ютерної програми не розвилася свідомість, а також здатність відчувати та бажати, як зазначає Ю.Н. Харарі [4, с. 138]. Однак може статися, що така унікальність - це лише питання часу, і людство вже скоро стикнеться з глобальнішою за всі часи свого існування світоглядною кризою.

Друга проблема полягає в тому, що якщо весь світ людської свідомості, отже, продукт її діяльності, який полягає у створенні моделей світу, звести до електричних імпульсів, то нескладно розробити технічні засоби для створення віртуальних світів. Ю.Н. Харарі пропонує звернутися до математики, щоби зрозуміти, що якщо це насправді так, то реальний світ буде лише одним, а віртуальних безліч, отже, вірогідність того, що ми живемо у реальному світі, дуже мала [4, с. 144]. В цьому разу знову постає стара філософська проблема доказовості реальності світу.

Таким чином, люди-алгоритми можуть набути нових властивостей, трансформувати своє життя та соціальні структури до невпізнанності. М. Каку вважає, що доля людства - це злиття з роботами. Він посилається на думку Р. Брукса, який колись очолював лабораторію штучного інтелекту, про те, що людині дуже не хочеться відмовлятися від свого особливого статусу, їй буде дуже складно погодитися з тим, що роботи можуть переживати справжні емоції, що роботи в принципі можуть бути живими. Однак Р. Брукс вважає, що нам доведеться погодитися 3 цим протягом найближчих п'ятдесяти років. Таким чином, Р. Брукс вважає, що людство зіллється з роботами [1, с. 354-355].

Людина може, наприклад, стати кіборгом, тобто підключити до свого тіла надможливості, як вважає М. Каку. «Скоро ми станемо справжніми кіборгами: неорганічні елементи перетворяться на невід'ємну частину нашого тіла, і наші можливості, бажання і сама особистість зміняться» [5, с. 479], - пише Ю.Н. Харарі. «Реальний потенціал технологій майбутнього, - продовжує він, можливість змінити самого Homo Sapiens, в тому числі його емоції і бажання» [5, с. 486]. Отже, на думку Ю.Н. Харарі, в майбутньому нас може очікувати нова "сингулярність», по інший бік якої вже нічого не матиме для нас сенс. Ю.Н. Харарі закликає замислитись над таким питанням: люди завжди уявляють майбутнє як покращене сьогодні, майже ніколи не думаючи про те, що в новій реальності їм взагалі може не залишитися місця. Нове, покращене, модернізоване кіберлюдство, цілком можливо, матиме зовсім інші властивості. 
Наша свідомість безпосередньо пов' язана з нашим тілом, досвідом його буття та взаємодії з навколишнім світом. Що буде, коли тіло отримає нові можливості? Зазнає змін досвід самоусвідомлення людини, отже, можуть змінитися їі відчуття, уява про цінності та цілі. Таким чином, великою є вірогідність того, що люди майбутнього не матимуть майже нічого спільного з нами. В цьому разі неможливо уявите, яка історія очікує людство. Зрозуміло тільки одне: «нова стадія історії передбачає не тільки технологічні та організаційні зміни, але й фундаментальне перетворення людської свідомості і особистості» [5, с. 489].

На відміну від Ю.Н. Харарі, М. Каку, який теж прогнозує кібермайбутнє для людини, вважає, що людяність як така нікуди не дінеться, незважаючи на суттєві трансформації тіла та свідомості. Причина цього полягає в принципі «печерної людини». «Принцип печерної людини полягає в такому: вибираючи між високими технологіями та людяним, емоційним підходом, ми завжди вибираємо людяне. <...> Річ у тім, що ми наслідували свідомість наших мавпоподібних предків. Деякі риси, що лежать в основі людської особистості, не змінювались, вірогідно, останні 100000 років з тих самих пір, коли в Африці з'явились перші сучасні люди. Суттєва частина нашої свідомості міркує про те, щоб добре виглядати в очах оточуючих, і намагається справити враження на друзів та представників іншої статі. Це міцно зашито в наш мозок» [1, с. 393-394]. Отже, М. Каку вважає, що надможливості для нашого тіла будуть використовуватися, скоріше, як опції, які можна вмикати та вимикати за необхідності. Вони, хоча й вплинуть на свідомість людини, проте не змінять її докорінно. Отже, навряд чи людство в сучасному стані завершить своє існування. Якщо Ю.Н. Харарі вважає, що нова історія людства буде мати фундаментальні відмінності, то М. Каку більш схиляється до думки про те, що загальні світоглядні характеристики залишаться без змін.

Ще однією проблемою майбутнього є форма існування свідомості. «Якщо вченим вдасться скопіювати мозок, тоді свідомість зможе існувати без матерії» [1, с. 357], - пише М. Каку. Можливо, свідомість звільниться від тіла та зможе блукати по Всесвіту як суто енергетичне створіння [1, с. 404]. Які можливості та загрози виникають при цьому? $\mathrm{V}$ що може вилитися втрата відчуття самості?

M Каку пише, що «свідомість у майбутньому взагалі може втратити концепцію «Я», або «самості», та увійти у так зване колективне всесвітне павутиння розумів. <..>> Заради ефективності та обчислювальних потужностей, можливо, доведеться відмовитись від власної ідентичності" [1, с. 442-443]. Виходить, що, з одного боку, індивідуальне «Я» та свобода волі не вписуються в сучасну наукову картину, а з іншого боку, відмова від них зруйнує сучасний світ. «Сумніви в тому, що свободи волі і неподільного «Я» не існує, виникали і раніше, але ж не вони не чинили особливого впливу на повсякденне життя» [4, с. 355], - пише Ю.Н. Харарі. Однак зараз людина все більше починає залежати від алгоритмів штучного інтелекту, ці алгоритми все сильніше виплітаються в наше життя і виникають питання стосовно того, яким чином буде відбуватися подальша взаємодія. На цьому шляху Ю.Н. Харарі вбачає дві перспективи, такі як техногуманізм і датаїзм. Якщо техногуманізм, погоджуючись із тим, що людство у теперішньому стані вичерпало себе, все ж таки сподівається за допомогою технологій створити модифіковану людину, то датаїзм вважає, що людство вже виконало своє завдання та має поступитися іншим формам [4, с. 411-412]. Датаїзм зазначає, що «біохімічні та електронні алгоритми підпорядковані одним і тим же математичним законам» [4, с. 430], отже, всі явища світу можна звести до обробки даних. Окрема людина втрачає свою унікальність та цілісність, зливається із загальним інформаційним потоком. «Відповідно до датаізму, <...> люди - не більш ніж інструменти для створення Інтернету всіх речей» [4, с. 446].

Таким чином, і М. Каку, і Ю.Н. Харарі сходяться на думці про те, що свідомість майбутнього вже не буде свідомістю індивідуальної людини в повному сенсі цього слова. Це може статися за різних причин, до яких належать здатність свідомості існувати незалежно від тіла, злиття зі штучними алгоритмами, але в будь-якому разі людина втратить свою цінність та здатність формувати систему сенсів. Її потреби, почуття та особливості більше не матимуть значення. Це однозначно свідчить про кінець ери гуманізму, але однозначні висновки робити ще рано. Можна тільки сказати, що процес перетворення вже почався, а питання щодо сенсу буття людини, які завжди перебували в центрі філософських роздумів, набувають неабиякої актуальності. Ю.Н. Харарі, наприклад, впевнений у тому, що зараз прийшов той час, коли треба замислитись над тим, якими ми хочемо стати. Чи не вперше в історії у філософії з'являється унікальна можливість не тільки визначати сутність людини, але й «програмувати» її, тобто розмірковувати над тим, якою саме людина має стати. В сучасну епоху такі проєкти вперше можуть із утопічних перетворитись на реальні.

Отже, перед філософією постає подвійне завдання. По-перше, під впливом сучасної науки руйнується гуманістична парадигма. Хоча ця ситуація і здається парадоксальною, тому що саме становлення цієї системи поглядів сприяло розвитку науки та техніки, уявляючи людину приборкувачем світу природи, зрештою, це привело до того, що технології вже майже підкорили людство, необхідність нової світоглядної системи 
$€$ очевидною. По-друге, філософія як найбільш загальна наука про людину має поміркувати над тим, які сенси та цілі можуть бути актуальними для нового людства. Зміни вже почались, навряд чи можна зупинити прогрес, але, можливо, є шанс вплинути на його результати.

Окрім того що трансформується сама людина, суттєво зміняться соціальні структури.

Разом із новим тілом і новими інтелектуаль-

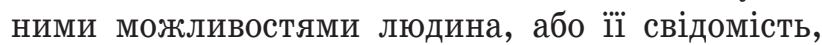
може стати безсмертною. Нічого подібного в істоpiї людства ще не було, тому складно навіть уявити, до яких наслідків приведуть такі можливості. I Ю.Н. Харарі, і М. Каку сходяться на думці про те, що майбутнє може стати епохою найбільш глобальної за всі часи людства нерівності. Тут ми знову стикаємося з парадоксом того, що ера небувалої рівності породжує еру небувалої нерівності.

М. Каку розмірковує над тим, чи не загрожують технології поділом людства на еліту та загальну масу, а також зауважує, що це навряд чи станеться, тому що досі навіть дорогі та ексклюзивні технології згодом ставали доступними широкому загалу та приносили користь, що, зрештою, покращувало життя людства загалом [1, с. 455]. «Більш того, не факт, що поява якихось можливостей із покращення інтелекту спричинить катастрофічний розкол, навіть якщо більшість не зможе дозволити собі цю процедуру. Значною мірою здатність вирішувати складні математичні рівняння або абсолютна пам'ять не гарантує успіху у представників протилежної статі, але ж саме ці стимули створюють мотивацію у більшості» [1, с. 457].

Ю.Н. Харарі висловлює більш категоричні думки про це. Надії на те, що технології з часом стають загальнодоступними, у XXI столітті можуть не виправдатися. Ю.Н. Харарі вважає, що якщо раніше медицина переважно займалась лікуванням хворих, то тепер вона переорієнтовується на вдосконалення здорових, а це вже проєкт елітарний, а не егалітарний, як було раніше [4, с. 407]. В майбутньому людство може розділитися кардинально за допомогою технологій удосконалення людини. Майже нічого не заважає вченим вивести новий біологічний вид надлюдей, які створять нову еліту. Ця еліта може настільки відрізнятись від мас своїм сприйняттям дійсності, емоціями, бажаннями та цілями, що масова людина вже ніколи не зрівняється з людиною нового зразка.

Отже, випливає багато складних запитань, зокрема питання про те, чи взагалі потрібна масова людина. Цілком зрозуміло, що економіка майбутнього вже не потребуватиме значної кількості робітників. Поступово усілякі експертні системи замінять людину в більшості сфер діяльності. Можливо, деякі професії не вдасться замінити штучними системами, але їх доцільніше буде доручити більш досконалим представникам людства. Чим будуть зайняті всі інші представники людства? Взагалі чи є для них місце в майбутньому?

Таким чином, зміни соціальної структури людства матимуть глобальний масштаб. Успіхи медицини та біотехнологій можуть зробити так, що людині зовсім не потрібно буде вмирати. Однак чи буде таке безсмертя загальнодоступним? Якщо ні, то це назавжди розколе людство і перегорне світоглядні системи. Навіть якщо так, то як це вплине, наприклад, на структуру сім'ї? Чим будуть займатися люди, які живуть скільки заманеться та не задіяні у процесі виробництва? Є припущення, що вони зануряться у більш цікавий віртуальний світ, тому ще одна можливість розвитку цивілізації це переселення у віртуальну реальність [1, с. 443]. Інші дослідники вважають, що в доісторичні часи суспільство непогано існувало і без особливої зайнятості, а основний час люди приділяли спілкуванню [6, с. 7]. Отже, замість того, щоб зникнути як непотрібне, масове суспільство може перейти на інший рівень та розгорнути свою діяльність у сфері спілкування [7, с. 164]. Ця ідея непогано співвідноситься з концепцією датаїзму, коли основна діяльність зводиться до породження та обробки даних.

Таким чином, М. Каку та Ю.Н. Харарі, хоча і сходяться на думці про те, що сучасні технології дуже сильно трансформують соціальний та взагалі культурний світ людини, проте все ж таки по-різному оцінюють ризики. М. Каку вважає, що технології не торкнуться найбільш глибокого рівня людської свідомості, отже, людина, хоча і зміниться, але не зникне зовсім. Ю.Н. Харарі припускає, що від людини взагалі може нічого не залишитися. Вона вже втрачає цілісність свого внутрішнього світу, а якщо ніякого центру свідомості не існує, то можна припустити, що поступово, крок за кроком, вона зміниться докорінно. На місце Homo Sapiens прийде Homo Deus, людина божественна, здатна створювати світ за своїм задумом, яка не буде мати нічого спільного з людиною сучасною.

Висновки. Розглянувши футурологічні концепції М. Каку та Ю.Н. Харарі, доходимо таких висновків. По-перше, і М. Каку, і Ю.Н. Харарі намагаються якомога краще зрозуміти, які соціально-антропологічні наслідки матимуть сучасні технології. Очевидно, що наука і техніка сьогодення вже не тільки допомагають людині у вирішенні певних завдань стосовно взаємодії з навколишнім світом, але й безпосередньо підходять до того, щоб цей світ змінювати. Зокрема, це стосується світу самої людини. Сучасні технології роблять одвічні мрії людства про безсмертя, про життя поза тілом та доступ до необмеженої інформації цілком реальними, але виявляється, що їх використання, скоріше за все, несумісно із сутністю людини.

По-друге, вони зауважують, що технології самі по собі ще нічого не вирішують. Те, як саме їх ви- 
користати, залежить від тієї чи іншої культури, тому цілком можливо, що найжахливіші прогнози не справдяться. Незважаючи на розвиток науки та її очевидні успіхи, як пише Ю.Н. Харарі, «міфи не втратили владу над людством, і наука тільки зміцнює цю владу. Замість того, щоб знищити інтерсуб'єктивну реальність, наука надаватиме їй можливість ще більшого контролю над об’єктивною і суб'єктивною реальністю. Завдяки комп'ютерам і біоінженерії різниця між вигадками і реальністю буде стиратися - за ступенем того, як люди будуть переробляти дійсність, щоб вона відповідала їх улюбленим казкам» [4, с. 211-212].

M. Каку вважає, що найбільш актуальне питання для сучасної філософії полягає в аналізі правомірності двох принципів, а саме принципу Коперника та антропного принципу. Принцип Коперника не залишає за людиною права щось «вирішувати» в межах Всесвіту. Антропний принцип, навпаки, стверджує, що життя взагалі та життя як буття людини вимагає дуже складного налаштування параметрів і не може бути випадковістю, отже, воно має фундаментальні підстави, які не може поставити під загрозу, зокрема, технічний прогрес.

В будь-якому разі сучасній філософії є над чим замислитись. Можна навіть стверджувати, що вона перебуває в унікальній ситуації, адже вперше за свою історію філософія має можливість розробити світоглядний проєкт майбутнього! Більш того, цей проєкт може бути покладено в основу трансформації людства, оскільки, очевидно, цей процес вже скоро стане суто технічною проблемою. Філософи мають замислитись над тим, які цінності та цілі мають бути покладені в основу майбутньої цивілізації, які відносини мають бути між людьми та людиною і навколишнім середовищем, передусім техносферою. Вперше в історії розвитку цивілізації може з'явитися можливість самостійно запрограмувати всі ці аспекти та виступити в ролі творців своєї історії.

\section{Jimepamypa}

1. Каку М. Будущее разума. Москва : Альпина нон-фикшн, 2015. $502 \mathrm{c.}$

2. Кобелєва Д.Л. Буття людини. Сучасність і майбутне (філософські роздуми щодо ідей Ю.Н. Харарі). Вісник Харківського національного університету ілені В.Н. Каразіна. 2020. № 61. Серія : Теорія культури і філософія науки. С. 90-96.

3. Кобелєва Д.Л. Концепція "Homo Deus" в історико-філософських працях Ю.Н. ХАРАPI. STUDIA SLOBOZHANICA : матеріали всеукраїнської науково-методичної конференції «Слобожанський гуманітарій - 2020» (м. Харків, 27 жовтня 2020 р.). Харків, 2020. С. 60-66.

4. Харари Ю.Н. Homo Deus: Краткая история завтрашнего дня. Москва : Синдбад, 2018. 496 с.

5. Харари Ю.Н. Sapiens: Краткая история человечества. Москва : Синдбад, 2018. 512 с.
6. Шипилов А.В. Будущее постсовременного общества: вперед в прошлое? Журнал социологии и социальной антропологии. 2018. № 21 (1). С. 7-26.

7. Шипилов А.В. Жизнь без труда? Это естественно. Социологический журнал. 2019. Т. 25. № 2. C. $153-170$.

\section{Анотація}

Кобелєва Д. Л. Сучасні технології та проєктування людства (спільне та різне у футуристичних концепціях М. Каку та Ю. Н. Харарі). - Стаття.

У статті розглянут філософські проблеми, пов'язані із застосуванням сучасних технологій у сфері трансформації людини. Спираючись на футуристичні концепції М. Каку та Ю.Н. Харарі, ми зробили спробу проаналізувати вплив науково-технічного прогресу на буття людини та людства загалом, а також зробити прогнози стосовного майбутнього цивілізації. М. Каку та Ю.Н. Харарі уважно розглядають різні аспекти сучасної науки та сучасних технологій, аналізують дослідження у сфері біології, когнітивних та комп'ютерних наук. В результаті цього вони доходять висновків, що в найближчому майбутньому людство переживе глобальніші за всю свою історію зміни. По-перше, дослідження мозку спонукають замислитись над тим, що таке свідомість людини, з чого вона складається та взагалі для чого вона існує. Таким чином, підривається віра в один із фундаментальних аспектів людини, а саме в її індивідуальне, цілісне «Я». Якщо «Я» не існує (принаймні в тому вигляді, як його розуміє сучасна культура), то виникають серйозні світоглядні проблеми, пов'язані 3 обгрунтуванням сучасної гуманістичної парадигми, яка є основою сучасного соціально-політичного устрою. По-друге, сучасні технології вже цілком здатні змінювати людину настільки, що виникають питання про те, чи це людина, чи вже зовсім нова істота, яка не має нічого спільного із сутністю людини. Програмування генотипу, створення кіборгів, перенесення свідомості до штучних систем, створення потужного штучного інтелекту - все це вже майже реальність, отже, культура та світогляд людства найближчим часом зазнають фундаментальних трансформацій. У зв'язку з цим перед філософією постають дуже важливі завдання, а саме проаналізувати наукові дані, сформулювати нову концепцію людини, визначити напрями та пріоритети подальшого розвитку цивілізації.

Ключові слова: людина, свідомість, індивідуальність, світогляд, культура, науково-технічний прогрес, майбутне.

\section{Summary}

Kobelieva D. L. Modern technologies and design of humankind (common and different in the futuristic concepts of M. Kaku and Yu. N. Harari). - Article.

The article deals with the philosophical problems associated with the application of modern technologies in the field of human transformation. Based on the futuristic concepts of M. Kaku and Yu.N. Harari, an attempt is made to analyze the impact of scientific and technological progress on the existence of man and humanity as a whole, and to make predictions about the future of civilization. M. Kaku and Yu.N. Harari consider various aspects of modern science and modern technologies, analyze 
research in the field of biology, cognitive and computer sciences. As a result, they conclude that in the near future humanity will feel the most global changes in its history. First, brain research encourages us to think about what human consciousness is, what it consists of and, in general, why it exists. Thus, faith undermines one of the fundamental aspects of man - in his/her individual, holistic "I". And if the "I" does not exist (at least in the form in which it is understood by modern culture), then there are serious worldview problems associated with the justification of the modern humanistic paradigm, which in turn is the basis of the modern socio-political system. Secondly, modern technologies are already quite capable of changing a person so much that the question arises whether it is a person or a completely new creature that has nothing to do with the essence of man. Genotyping, the creation of cyborgs, the transfer of consciousness to artificial systems, the creation of powerful artificial intelligence - all this is almost a reality, and therefore, the culture and worldview of mankind will soon undergo fundamental transformations. In this regard, philosophy faces very important tasks: to analyze scientific data and formulate a new concept of man, to determine the directions and priorities for further development of civilization.

Key words: man, consciousness, individuality, worldview, culture, scientific and technological progress, future. 